\title{
Overcoming the Trickle-Down Effect Through Financial Inclusion Towards the Industrial Revolution 4.0 Building from the Edge
}

\author{
I Putu Gede Diatmika ${ }^{1, *}$ Gede Adi Yuniarta ${ }^{1}$ Putu Yunartha Pradnyana Putra ${ }^{1}$ \\ ${ }^{1}$ Department of Economics and Accounting,, Universitas Pendidikan Ganesha, Singaraja, Indonesia \\ ${ }^{*}$ Corresponding author. Email: gede.diatmika@undiksha.ac.id
}

\begin{abstract}
High economic growth can encourage income distribution and can reduce poverty. One important factor that needs to be considered is that the skills and competencies of human resources must be consistently improved according to the needs of the growing labor market. The article is going to reveal the role of banks in implementing rural community empowerment to overcome trickle-down effect through financial inclusion policies towards the industrial revolution 4.0 and the role of banking in encouraging financial inclusion policies to move the real sector of rural communities in overcoming poverty trickle-down effect and overcome the difficulties of the industrial revolution 4.0. A descriptive qualitative approach was implemented. Badung Regency, Mengwi District, was the setting to collect data. The results showed the banking sector has collaborated with the Tri Eka Bina Artha Mulia Cooperative to utilize a powerful banking product, namely one-handed transactions with the aim of making it easier for the public or customer to obtain banking services. Source of funding for various community activities to improve the welfare of the community in Badung Regency, Mengwi District. Through financial inclusion, the banking sector in facing the 4.0 industrial revolution, building from the periphery, making the process of transaction and developing business easier, one-handed transactions help customers or people who live in villages to be able to transact both in the form of deposits, deposits and credit through Bank Negara Indonesia 46 agents, Bank Rakyat Indonesia Link and Automated Teller Machines as well as providing monthly payment services for consumer obligations such as payments for electricity, water, cellular phone credit, electricity credit, insurance, Social Security Administering Body.
\end{abstract}

Keywords:, Financial inclusion, Industrial Revolution 4.0, Trickle-down effect.

\section{INTRODUCTION}

The main challenge for Indonesia's more substantial democracy is how democratic government is able to improve people's welfare, in order to reduce poverty and inequality, through various social welfare development programs. The government and the community have a responsibility and have a correlation in overcoming the problems of poverty and inequality. In order to remove the barriers of poverty and inequality, implementing inclusive development policies is needed. "Inclusive development" refers to a process in which all aspects of society, including basic infrastructure and services, have access to the benefits of progress.

Despite growth of economic, in developing countries, unemployment and poverty are easily observable [1].
Community active participant and government is needed to overcome the problems. The Jokowi government has launched social welfare development that emphasizes an inclusive approach. Bring back the state to protect the whole nation, build Indonesia from the periphery, improve the quality of life of Indonesian people.

The development program is prioritized on opening access and opportunities for lower-class communities, including in rural and remote areas, to increase the scale of economic activity and welfare. This commitment can be seen, among others, from the massive physical infrastructure development in various regions to remote areas. Opening isolated areas, providing equal access to rural communities, providing equal access to education and health services between urban and rural areas not only has an impact on a balanced income distribution, but 
also provides equal opportunities for all regions and communities to obtain equal accessibility. equal to all economic resources of the nation. Inclusive development significant is higher due to the development of technology, internet, and cloud computation. Soon, human is going to be replace by artificial intelligence. As the result, many jobs will be disappeared. To achieve this goal, inclusive growth depends on three important components, namely the success of maximizing economic opportunities or opportunities for all levels of society and the availability of social safety nets for all levels of society and the success of ensuring equitable access to employment opportunities.[2]

Faced with the challenges and the need to build community resilience in a sustainable manner in the industrial era 4.0, it is necessary to make efforts to create competent human resources, provide entrepreneurial assistance, advocate for women regarding their rights and how to access these rights, encourage workers to dare to claim their rights and open public access to banking facilities. Knowledge of how to save and invest can help economic growth and overcome the trickle-down effect. The role of banking in educating is needed.

One of the potential programs for overcome trickledown effect is through financial inclusion. Presidential Regulation No. 82/2016 concerning the National Strategy for Financial Inclusion, stated that equal access to formal financial service with good manner and affordable is needed to gain financial inclusion. People access financial services for payments, savings, credit, investment, insurance and others. Financial inclusion can be trusted overcome trickle-down effect in Indonesia. Financial inclusion not only overcomes the trickle-down effect, but also reduces income inequality [3].

The momentum of the existence of village funds that is driven by the government with the aim of building from the periphery should be supported by financial industry regulators to move the real sector at the lowest level of society, the largest community group that can become the fundamental basis of the national economy. With the development of the industrial revolution 4.0, the financial industry should be able to collaborate with players in the financial industry, especially banking and fintech, to become a catalyst for the movement of the real economic sector of marginalized communities and rural communities [4]. In this case, the need for a more just and transparent financial and banking system arrangement, which can encourage broad public participation and empower the community. Rural areas are very wide with a very large population and low levels of income, education and health status, plus accessibility to productive factors, business capital and investment, as well as in obtaining information is very weak, so that progress and prosperity in the existing community in rural areas far behind compared to urban communities. This can be done through financial inclusion in the financial and banking system. The importance of the role of the financial and banking industry in strengthening national economic fundamentals through community empowerment and building from the periphery with efforts to move the real sector of rural communities, so that rural communities can maintain the technological challenges.

\section{METHOD}

This study describes and analyzes the role of banks in implementing rural community empowerment to overcome trickle-down effect through financial inclusion policies towards the industrial revolution 4.0 and the role of banking in encouraging financial inclusion policies to move the real sector of rural communities in overcoming poverty trickle-down effect and dealing with the challenges. A descriptive qualitative approach was used. Badung is used as the site of the study. Interview, observation, and documentation were carried out to collect the data. This study used Small and Medium Enterprises in Mengwi sub-district as subjects of study. This study uses qualitative data. Qualitative data is sourced from the implementation of field surveys, both through research instruments and indepth-interviews. Qualitative data obtained through indepth interviews, observation and content analysis [5]. Data reduction, presentation, and drawing conclusion were carried out. The data was in the forms of text and figures. [6].

\section{RESULTS \& DISCUSSION}

\subsection{Role Banking in Implementing Rural Community Empowerment to Overcome Trickle Down Effect Through Financial Inclusion Policy Towards the Industrial Revolution 4.0}

Banking in people's lives, especially in Badung Regency, Mengwi District, is one of the agents of development. National banking plays an important as well as strategic role, especially in relation to the provision of capital for the development of the productive sector in overcoming the problem of the trickle-down effect. The public has high hopes for banking, because the Bank is a financial institution that plays a very important role in carrying out economic and trade activities. Banks as locomotives of economic development have several objectives, namely, encouraging and accelerating the economic progress of the community by carrying out all banking, financial and investment activities, enhancing wealth and minimizing the inequality.

Technological era has been an opportunity for banks to be more innovative in providing services to the community and empowering the community so that people can become empowered in facing the industrial 
revolution 4.0. These innovations are needed to overcome the trickle-down effect through financial inclusion and respond to competition in line with the rapid growth of financial technology. The development of small and medium enterprises is certainly closely related to the availability of capital that needs to be considered, because basically capital is the thing that needs to be prioritized. So far, the problems that are often faced by Small and Medium Enterprises are internal problems, namely the lack of capital and limited access to financing. Small and Medium Enterprises strategically help economic growth through distribution and employment.

Efforts have been made by the Bank in Badung Regency, Mengwi District, by embracing Small and Medium Enterprises in Mengwi District to become agents with an online system. Banking in developing and implementing these strategies consistently to add value to relationships by involving Small and Medium Enterprises in strategic dialogue and assisting in building businesses and businesses proactively. The Bank also embraces the community in Mengwi District in collaboration with the Millennial Cooperative by promoting a new style of Millennial Cooperative operation through one-handed transactions. This is reinforced by the statement of an informant who has used one-handed transactions in Mengwi District, namely Mr. Nyoman Raka Sutamaja, a Garment and Catfish Entrepreneur, who stated that;

"...one-handed transactions are very useful, because with the technology-based program from the banking side, it can make it easier for small and medium businesses and no longer have to queue at bank tellers, one-handed transactions can be used for inter-bank transfers, buying cellphone credit and electric pulses and can also be used to pay water bills...."

This is due to the area of residence that is far from the Bank or due to requirements that are burdensome to the public or customers. Through this financial inclusion, the banking sector in facing the industrial revolution 4.0 builds from the periphery, has invited the participation of the community to help developing transaction and business. This one-handed transaction helps customers or small and medium business actors who live in villages to be able to make good transactions. in the form of deposits, deposits and credit through these agents as well as providing monthly payment services for consumer obligations such as payments for electricity, water, cellular phone credit top-ups, electricity credits, insurance, Social Security Administering Bodies and all forms of community installment products at institutions. other finances.

\subsection{Banking Role in Encouraging Financial Inclusion Policies to Mobilize the Real Sector of Rural Communities in Overcoming Trickle Down Effect and Enhancing Opportunity to in the Industrial Revolution 4.0}

The success of SMEs in developing a business automatically can also provide benefits for the Bank that has provided guidance, these benefits can be in the form of smooth credit and interest payments and any funding needs for the development of small businesses that have been fostered and make choices to the Bank that has helped and fostered it. Banks apply appropriate financial principles to realize financial inclusion and encourage equity in increasing economic growth and community welfare. In Badung Regency, Mengwi District, the role of banks in encouraging financial inclusion policies by mobilizing the real sector of society in overcoming trickle-down effect and dealing with challenges of the 4.0 era.

The banking sector has collaborated with the Tri Eka Bina Artha Mulia Cooperative. The Tri Eka Bina Artha Mulia Cooperative utilizes its products in the form ofonline and collaborate with banks with powerful banking products, namely one-handed transactions with the aim of making it easier for customers or small and medium businesses to obtain banking services and obtain sources of funding for various community activities or small and medium entrepreneurs to improve welfare in Badung Regency, Mengwi District. This is reinforced by the statement of Mr. Mande Mahardika, Contractor and Building Shop Entrepreneur which states that;

“......That's right, cooperative Tri Eka Bina Artha Mulia very useful for the community in Mengwi

District in particular, I myself have felt the benefits of one-handed transactions through cooperatives Tri Eka Bina Artha Mulia which apparently also cooperates with public banks in the Bali area ..."

Furthermore, Mr. Mande Mahardika, Contractor and Building Shop Entrepreneur also explained that;

".... there are many customers who transact in cooperatives Tri Eka Bina Artha Mulia, the people here are very enthusiastic and feel the benefits of the cooperative Tri Eka Bina Artha Mulia. We hope that as a community, government or banking parties will be able to care more about the community, especially people who still need capital for their business development and that banking products will be reproduced and introduced to the public so that people know more about what banking products are in helping the economy public...."

Banking has a close relationship in improving people's welfare through financial inclusion policies. 
Various internal factors drive the opportunities of business and the changes. Businessmen should grab the opportunities by enhancing the use of technology in developing business, such as using business strategy application, marketing products, and giving services. Another sector that could use technology is business communication among employees, consumers, or clients. The use of virtual meeting could also ease the business communication and development. For this reason, the role of banking must be optimized in various aspects of people's lives in rural areas because limited facilities and remote areas can slow down access to rural communities. So that the role of banking in overcoming the trickledown effect through financial inclusion can be implemented and can be felt by rural communities, the better the function and implementation of banking operations, the greater the contribution of banking to economic growth and the suburbs are better prepared to face the challenges of the industrial revolution 4.0 going forward. the role of banking must be optimized in various aspects of people's lives in rural areas because of limited facilities and far-reaching areas that can slow down access that must be accepted by rural communities. So that the role of banking in overcoming the trickle-down effect through financial inclusion can be implemented and can be felt by rural communities, the better the function and implementation of banking operations, the greater the contribution of banking to economic growth and the suburbs are better prepared to face the challenges of the industrial revolution 4.0 going forward. the role of banking must be optimized in various aspects of people's lives in rural areas because of limited facilities and farreaching areas that can slow down access that must be accepted by rural communities. So that the role of banking in overcoming the trickle-down effect through financial inclusion can be implemented and can be felt by rural communities, the better the function and implementation of banking operations, the greater the contribution of banking to economic growth and the suburbs are better prepared with the challenges.

\section{CONCLUSION}

Banks apply appropriate financial principles to realize financial inclusion and encourage equity in increasing economic growth and community welfare. Trickle-down effect and in dealing with 4.0's challenges. The banking sector has collaborated with the Tri Eka Bina Artha Mulia Cooperative which utilizes its products in the form of online products and collaborates with banking parties with powerful banking products, namely one-handed transactions with the aim of making it easier for the public or customers to obtain banking services and in obtaining banking services.source of funding for various community activities to improve the welfare of the community in Badung Regency, Mengwi District. Through financial inclusion, the banking sector in facing the industrial revolution 4.0 builds from the periphery, has invited the participation of the community to make it easier for the community to transact and in developing their business, one-handed transactions help customers or people who live in villages to be able to transact both in the form of deposits, deposits and credit through Bank Negara Indonesia 46 agents, Bank Rakyat Indonesia Link and the SERACA Automated Teller Machine as well as providing monthly payment services for consumer obligations such as payments for electricity, water, cellular phone credit, electricity credit, insurance.

\section{REFERENCES}

[1] H. Warsilah, "Inclusive Development Approach For Reducing Social Exclusion In Urban Area A Case Study Of Marginal Groups In Kampung Semanggi," J. Soc. Cult., 2015.

[2] M. K. and J. Z. (eds [1] H. Hill, "Diagnosing the Indonesian Economy: Toward Inclusive and Green Growth." London: Anthem Press for the Asian Development Bank," 2012.

[3] C. Y. Park and R. V. M. Jr., "Financial Inclusion, Poverty, and Income Inequality in Developing Asia," ADB Econ. Work. Pap. Ser., 2015.

[4] Muslims, "Building Financial Inclusion," 2018. https://www.katalampung.com/2018/11/mengbang un-keuangan-iklusif-dari.html.

[5] L. Moleong, Qualitative Research Methodology. Bandung: PT. Rosdakarya.

[6] Sugiono, Combination Research Methods, Mix Methods. Bandung: Alfabeta, 2015. 